\title{
Low-cost modified endoscopic vacuum therapy using a triple-lumen tube allows nutrition and drainage for treatment of an early post-bariatric surgery leak
}

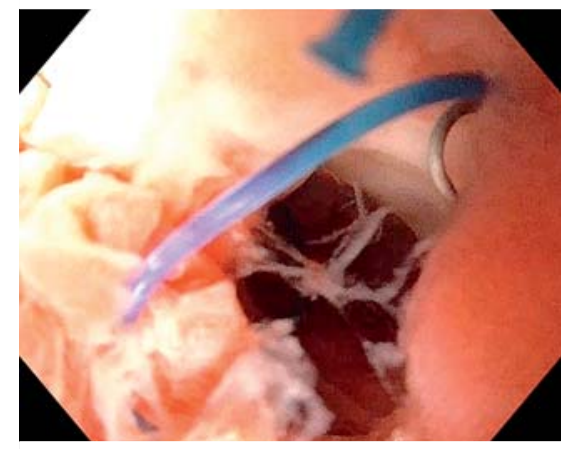

- Fig. 1 Underwater endoscopic visualization of the sleeve leak.

Leaks after laparoscopic sleeve gastrectomy (LSG) occur in up to $5 \%$ of patients, with mortality rates approaching 4\% [1]. Among available therapies for leaks after bariatric surgery, endoscopic approaches have been shown to be safe and effective. Tissue sealants, cap-mounted clips, suturing, stents, a cardiac septal defect occluder, septotomy, endoscopic internal drainage with double pigtails, and endoscopic vacuum therapy (EVT) are the forefront of the therapeutic endoscopic arsenal [2,3]. However, an individualized approach is needed to determine the best endoscopic treatment strategy for a given patient. In this video, we describe the successful treatment of a LSG leak using low-cost modified EVT.

A 30-year-old woman with class II obesity developed fever, nausea, and abdominal pain 14 days after LSG. Computed tomographic scan revealed a leak associated with a small contained collection adjacent to the staple line of the proximal stomach (angle of $\mathrm{His}$ ). Underwater esophagogastroduodenoscopy was performed without air insufflation to avoid disrupting the collection (> Fig. 1). The patient was treated with modified EVT using widely available triple-lumen tubing to allow for nutrition using the jejunal tube and EVT using the fenestrated portion of the tube ( $\vee$ Video 1 ). The procedure was well tolerated and the patient

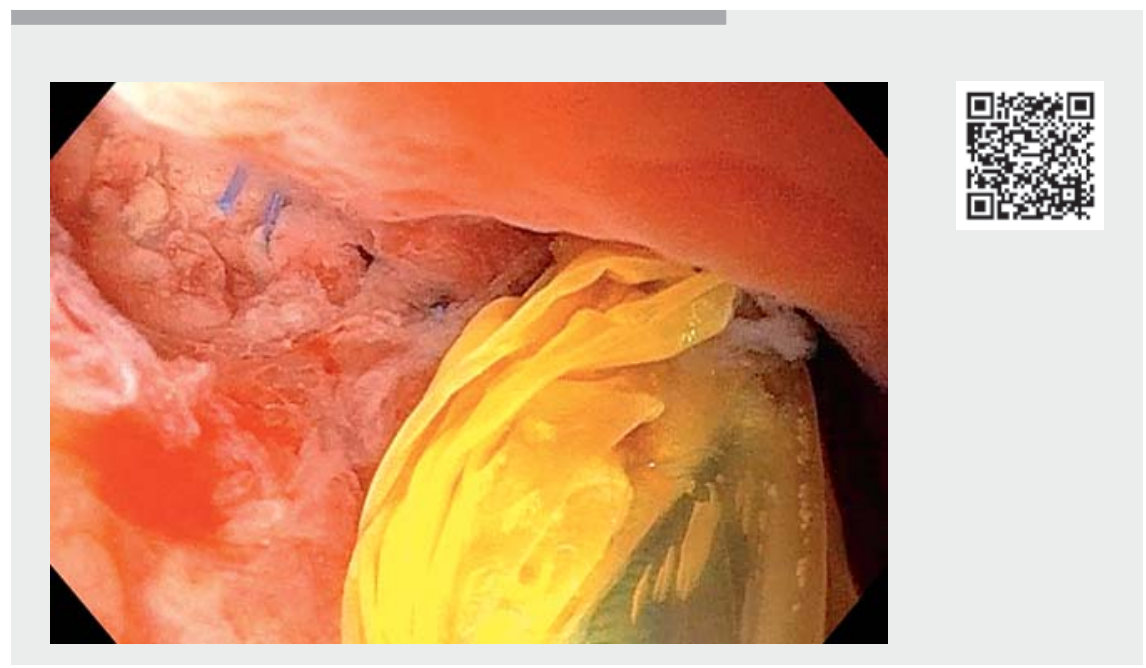

Video 1 Low-cost modified endoscopic vacuum therapy with a triple-lumen tube.


Fig. 2 Fluoroscopic imaging confirmed the success of leak treatment with the low-cost modified endoscopic vacuum therapy (EVT) system and demonstrated a significant improvement in the sleeve stenosis.

remained on enteral nutrition as well as taking a liquid diet on the day following the procedure. External drainage was not required. After 15 days, imaging demonstrated resolution of the leak ( $\triangleright$ Fig. 2 ), and the modified EVT system was removed (> Fig. 3 ).

In summary, endoscopic drainage with this low-cost, modified EVT is a highly effective and safe technique for leaks [4,
5]. Furthermore, EVT obviates the need for external drainage and employs widely available materials. Ultimately, this lowcost modified EVT allows for nutrition and drainage with a single tube through the nares, enabling decreased procedure times, longer periods between EVT system exchanges, and fewer adverse events. 


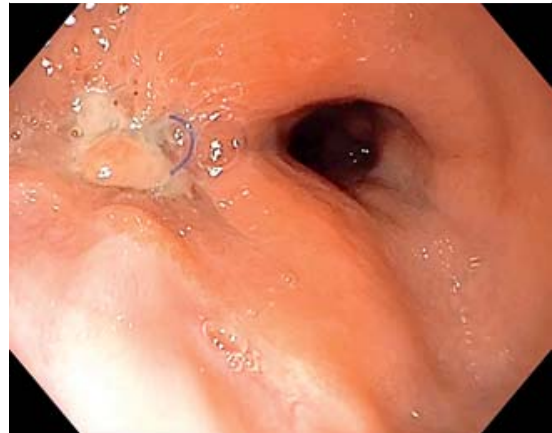

- Fig. 3 Complete healing of the leak after one session of the modified EVT treatment.

Endoscopy_UCTN_Code_TTT_1AO_2AI

\section{Competing interests}

The authors declare that they have no conflict of interest.

The authors

Diogo Turiani Hourneaux de Moura ${ }^{1}$, Bruno Salomão Hirsch ${ }^{1}$, Mateus Bond Boghossian ${ }^{1}$, Flaubert Sena de Medeiros², Thomas R. McCarty ${ }^{3}$, Christopher C. Thompson ${ }^{3}$, Eduardo Guimarães Hourneaux de Moura ${ }^{1} \odot$

1 Gastrointestinal Endoscopy Unit, Gastroenterology Department, Hospital das Clínicas da Faculdade de Medicina da Universidade de São Paulo, São Paulo, Brazil

2 Surgery Division, Federal University of Rio Grande do Norte, Natal, Brazil

3 Gastroenterology, Hepatology and Endoscopy Division - Harvard Medical School, Brigham and Women's Hospital, Boston, Massachusetts, USA

\section{Bruno Salomão Hirsch, MD}

Av. Dr Enéas de Carvalho Aguiar, 225, $6^{\circ}$ andar, bloco 3, Cerqueira César, 05403-010 - São Paulo, SP, Brazil brunosalomah@hotmail.com

\section{References}

[1] Hamid HKS, Emile SH, Saber AA et al. Customized bariatric stents for sleeve gastrectomy leak: are they superior to conventional esophageal stents? A systematic review and proportion meta-analysis Surg Endosc 2021; 35: 1025-1038

[2] de Moura DTH, Sachdev AH, Thompson CC. Endoscopic full-thickness defects and closure techniques. Curr Treat Options Gastroenterol 2018; 16: 386-405

[3] do Monte ES Jr, de Moura DTH, Ribeiro IB et al. Endoscopic vacuum therapy versus endoscopic stenting for upper gastrointestinal transmural defects: systematic review and meta-analysis. Dig Endosc 2020. doi:10.1111/den.13813

[4] Loske G, Schorsch T, Rucktaeschel F et al. Open-pore film drainage (OFD): a new multipurpose tool for endoscopic negative pressure therapy (ENPT). Endosc Int Open 2018; 6: E865-E871

[5] de Moura DTH, de Moura BFBH, Manfredi MA et al. Role of endoscopic vacuum therapy in the management of gastrointestinal transmural defects. World J Gastrointest Endosc 2019; 11: 329-344
Bibliography

Endoscopy 2022; 54: E376-E377

DOI 10.1055/a-1540-5870

ISSN $0013-726 \mathrm{X}$

published online 9.8.2021

(C) 2021. Thieme. All rights reserved.

Georg Thieme Verlag KG, Rüdigerstraße 14, 70469 Stuttgart, Germany

\section{ENDOSCOPY E-VIDEOS}

https://eref.thieme.de/e-videos

口回 Endoscopy E-Videos is an open access online section, 自嗮: reporting on interesting cases and new techniques in gastroenterological endoscopy. All papers include a high quality video and all contributions are freely accessible online. Processing charges apply (currently EUR 375), discounts and wavers acc. to HINARI are available.

This section has its own submission website at https://mc.manuscriptcentral.com/e-videos 